\title{
REGIONAL CURRENCY UNIONS AND SUPRANATIONAL CURRENCY ${ }^{1}$
}

Creation of voluntary regional economic alliances of independent countries was an important area of development of the regional and world economy at the end of XX-th century. They arise as a reaction on the dominance of the world's few national currencies, playing a world level role. A basic feature characterizes trade relations in the framework of such alliances - a departure from the world's currencies and the use of specially created regional ones. Practically the main obstacle to the emergence and spread of such unions is instability of regional currencies associated with their binding to one of the national currencies of the country - a member of the Union or to the gold standard.

The article describes the theoretical solution and practical mechanism for creating independent of any national currency or gold, a supranational currency. The purchasing power of such a currency is determined by a specially created benchmark of purchasing power. It is demonstrated that the currency of this type allows using regional currencies without discrimination of member countries of the regional union. Also, there are given arguments about the prospect of using such currencies as the world's.

Keywords: regional currency, world currency, supranational currency, the purchasing power of currencies' benchmark

\footnotetext{
${ }^{1}$ @) Asaliev A. M., Jusim V. N., Tarkhova L. S., 2014. Text.
} 


\section{The basic problem of regional currencies}

The idea of using intergovernmental regional currencies, alongside with or instead of acknowledged world ones, got powerful supporters such as the leaders of the largest countries after the crisis of 2008. Their position is justified by the dissatisfaction with the world currency-financial system having shaped by the beginning of XX1 century.

The claims to it in a popular form have been formulated in the article by Nursultan Nazarbaev, President of Kazakhstan [12]. He named a number of the system faults. In particular, not equal terms of currencies evaluation of the countries-technological leaders (USA, EU) and other national currencies; uncontrollability of the system by its subjects-users (countries, companies and citizens); unacceptably low efficiency of the currency-financial system in general. The latter claim to the currency-financial system is closely connected with the world crisis of 2008.

Russia's position regarding this issue is the following: "Euro should strengthen. In Asia there should appear national reserve currencies. Ruble may become, anyhow, reserve regional currency" [19].

The experts note pros and cons for the country the currency of which will become the main regional one [12]. However, in the matter of regional currency introduction feasibility the current economic targets actually start playing the second fiddle in comparison with the political tasks and, consequently, strategic economic goals.

The Russian leaders' interest in a regional currencies problem is far from being abstract. Russia tries hard to create efficient economic space out of the neighbor countries, the former CIS states and, perhaps, a wider range. In any case the task of expansion and deepening of the Customs Union of Republic of Belarus, Republic of Kazakhstan and Russian Federation (EurAsEU).

At the same time the systematic problem of Customs Union development means a transition of its participants in their trade relations towards regional currency. And here the position of Russia's main partner in the integral economic space is obvious. It arises from President's of Kazakhstan requirements to world currency. It's only natural any intergovernmental regional currency should solve the same problems in states' relations as a world currency but at a smaller scale. And concerning world currency President of Kazakhstan expressed himself quite clearly, "It is nonproductive to use national currency of any state as world currency". And, moreover, he considers that there should be a specific law where "principally supranational intergovernmental status of the cur- rency and the principals of its emission are clearly and unambiguously defined by specially designed World Emission Centre". [12]

But what interferes with the make up of such a world and then regional currency?

It is considered that the problem, which is needed to got over on the way to making up an efficient world and regional currency is a paradox or a dilemma by Triffin $[4,6,26]$. The paradox is formulated as a contradiction between the international origin of usage and its national origin.

What's the impact of Triffin's paradox and can it be overcome?

In essence, the requirements towards world (regional) currency are apparent from its function at trade transactions with the goods which prices are quoted in different national currencies. At the surface the main task of such a currency is to play the part of a standard, in the units of which the value of two goods expressed in a national currency can be compared.

Actually, the problem is not solved by only making up a standard or in other words an ideal supranational currency playing its part. The objective comparison of purchasing values suggests the possibility to do it very precisely.

In the above assumption two independent problems, that as it is believed don't have even a principal solution not to mention a practical one, have been revealed. Indeed, in economic theory it is universally recognized that a natural standard of purchasing power doesn't exist and an artificial one cannot be created.

The accuracy of currency purchasing power assessment is determined by stock exchange quotation accuracy and judging by the fact that it is practically the only comparison mechanism because the better one hasn't been invented.

The solution of both the problems is by the highest standards prevented by the natural origin of any existent currency.

Actually, the problem of making up a standard of even only a national currency is connected with the fact that purchasing power of its unit reflects an averaged value of millions of daily transactions, exclusively within the frames of a national market. And to register at least half of them is believed unreal.

The task of accuracy increase of purchasing power assessment of two national currencies requires the use of already supranational purchasing power standard and also a common supranational mechanism of its use in every sovereign country. And this is even more so is considered unreal.

However, serious research has shown "unacceptability of using value currency rates in inter- 
national assessments" [7]. Quotations of national currencies are actually influenced by such factors as current currency demand and supply, inflation expectations, Central Bank policy, some political events and many others [6,20,26,27]. And all of them influence purchasing power only indirectly via stock exchange quotations changing export and import prices.

Meanwhile, real purchasing power of national currency may not change at all (there is neither inflation nor deflation) or change not like currency quotations.

But this means that currency purchasing power assessment by means of stock exchange quotations includes a nonfunctional constituent. They are determined with a very big, from the point of view of a number of practical tasks, intermittent error. Such facts as, for example, economically unjustified fall in a US dollar rate after 11 September or unexampled fall in British currency rate, pound sterling, in 1992 as the result of one person speculations, as many people believe, George Soros [8].

In reality a large tragedy occurred on 11 September hardly influenced the US economy and Soros's speculation is not connected at all with actual economic processes. It is confirmed by the fact that after some time the currency quotations of the economies of both the countries returned to their previous values without any additional changes.

In general a stock exchange is one of the most outstanding inventions of the civilization. However, regarding the currency relevant purchasing power this mechanism has extremely become out of date.

The fact that while assessing such a fundamental index as gross domestic product (GDP) they have globally started to use not currency quotations but value of their purchasing power expressed by means of Purchasing Power Parity (PPP) can serve as an indirect but important index of incorrectness of comparative assessments of currency purchasing power on the basis of stock exchange quotations.

It may seem that the principle of its estimation, quite successfully illustrated by the "Big Mac" example, allows to escape the necessity of assessing the purchasing power of each of the two compared currencies individually. Indeed, the comparison of the prices on a practically identical product (Big Mac) in two countries should give an idea of two currencies purchasing power correlation irrespective of purchasing power of each of the currencies separately. But it is not the case.

Correlation of the prices on absolutely similar "Big Macs" in two countries only illustrates the assessment method of purchasing power parity and in reality it is not used for a very simple reason. This correlation may be quite uncharacteristic for the majority of other similar goods in these countries and does not reflect purchasing power of national currencies in transactions with the goods not traded in other countries [27]. Thus, on the basis of price correlation in different currencies of one product or a small number of goods it is possible to estimate purchasing power parity only with a big uncertainty or error. It is directly connected with a fundamental characteristic of currency purchasing power: its exclusively averaged value /see section $4 /$.

The purchasing power parity (PPP) is not determined at the stock exchange but estimated. A certain method of international comparisons is applied. "The UNO program of international comparisons is a universally recognized statistic standard in the area of world comparisons" [11]. The problem is that PPP estimation in accord with this method brings about in a number of cases the appearance of an unacceptably big and what is more important system error.

It is notwithstanding that the error is system-defined but not an intermittent one. Such a conclusion is drawn from the GDP values analysis got while using currency rates and their purchasing power parity (see Table).

In table one the countries with the population of more than $50 \mathrm{ml}$ people are shown. The countries are ranked according to the decrease of their economic development level, defined by GDP level (estimated with PPP use) per capita. The last column illustrates the correlation of GDP in US dollars, estimated with PPP use, to the same GDP but calculated at official rate.

It has turned out that all the countries, the level of well-being of which is over 18-20 thousand US dollars per capita, have the correlation of the two estimated values of GDP lower than 1 and the difference in the GDP values is comparatively low, about $20 \%$. And all the countries, the level of well-being of which is lower the above mentioned, the correlation of the two GDP values is substantially more than 1 . One can mention here the model difference in GDP value, estimated according to the rate and parity, not in 205 but in 150$200 \%$. The same effect can be noticed in all the rest countries of the world throughout the other years besides rare exceptions.

It means that there are two nonrandom tendencies. The error level is associated with the country development level, and more over, the error character also depends on country economic and technological development error. Thus, in a 
Table

Difference in GDP value of big countries in 2012 calculated on the basis of PPP and US dollar [14], rate (in US dollars in 2012)

\begin{tabular}{|c|c|c|c|c|c|}
\hline & Country & $\begin{array}{l}\text { GDP per capita on the basis of PPP } \\
\$ / \text { per person per year }\end{array}$ & $\begin{array}{l}\text { GDP on the basis } \\
\text { of PPP bln \$ }\end{array}$ & $\begin{array}{l}\text { GDP on the rate } \\
\text { basis, bln } \$\end{array}$ & Ratio \\
\hline 1 & USA & 49800 & 16,24 & 15,68 & 1,04 \\
\hline 2 & Germany & 39100 & 3,38 & 3,40 & 0,99 \\
\hline 3 & Great Britain & 36700 & 2,37 & 2,43 & 0,97 \\
\hline 4 & Japan & 36200 & 4,49 & 5,96 & 0,75 \\
\hline 5 & France & 35500 & 2,37 & 2,61 & 0,91 \\
\hline 6 & Italy & 30100 & 2,02 & 2,01 & 1,00 \\
\hline 7 & Russia & 17700 & 3,37 & 2,01 & 1,67 \\
\hline 8 & Mexico & 15300 & 2,02 & 0,874 & 2,31 \\
\hline 9 & Turkey & 15000 & 1,36 & 0,614 & 2,21 \\
\hline 10 & Brazil & 12000 & 2,33 & 2,25 & 0,99 \\
\hline 11 & Thailand & 10000 & 0,64 & 0,36 & 1,78 \\
\hline 12 & China & 9100 & 12,27 & 8,23 & 1,49 \\
\hline 13 & Egypt & 6600 & 0,53 & 0,26 & 2,04 \\
\hline 14 & Indonesia & 5000 & 1,2 & 0,88 & 1,36 \\
\hline 15 & Philippines & 4300 & 0,42 & 0,25 & 1,68 \\
\hline 16 & \begin{tabular}{|l|} 
India \\
\end{tabular} & 3900 & 4,71 & 1,84 & 2,56 \\
\hline 17 & Vietnam & 3500 & 0,34 & 0,14 & 2,43 \\
\hline 18 & Pakistan & 2900 & 0,49 & 0,23 & 2,13 \\
\hline 19 & Nigeria & 2700 & 0,45 & 0,26 & 1,73 \\
\hline 20 & Bangladesh & 2000 & 0,29 & 0,12 & 2,42 \\
\hline 21 & Ethiopia & 1200 & 0,11 & 0,03 & 3,67 \\
\hline 22 & Kongo & 400 & 0,027 & 0,015 & 1,80 \\
\hline
\end{tabular}

number of cases there happens a substantial system error while estimating currency PPP.

At the same time, the task of dramatic increase in estimation accuracy of currency purchasing power is solvable. So is the demand for estimation independence from a particular national currency.

The solution shows up when a virtual currency purchasing power standard is being set up.

\section{The principle of setting up a virtual currency purchasing power standard}

We are going to show a possibility of setting up an independent currency purchasing power standard on the example of a national currency and, moreover, demonstrate that its prototype has been long used in economic theory and practice. In essence, the principle of setting up a currency purchasing power standard doesn't differ at all from setting up any other standard, for example, that of mass or length.

The task is always related to the choice of measurement unit, provision of its invariability in time and possibility of comparing (measuring) all analogue values of a chosen unit.
The standard of a purchasing power should be arbitrary but invariable, convenient for measuring and universally recognized.

When talking about purchasing power something should be taken as a value of purchasing power equal to 1 , provide its invariability, which practically means set up a standard, and secure a reliable means of comparing all other carriers of purchasing power with this standard. The latter just means the possibility of estimating currency purchasing power in the values of this standard.

Actually, just like the above mentioned but temporary purchasing power standard has always been used for comparison of GDP values of a country in various years. In this case a currency purchasing value of practically any year is taken. So not long ago when estimating the values of "real" USA GDP for the last ten years the dollar purchasing power in 2000 was taken as a basis and then that of 2009. Thus, the principle of using a basis for a comparative current purchasing power estimation has worked for a long time.

Moreover, when we say, "ruble inflation was $10 \%$ last year", we practically estimate the change of currency purchasing power using as a standard 
or a basis for comparison purchasing power of a ruble of a previous year.

The opinion of impossibility of purchasing power standard setting up is likely to have appeared because the method of its setting up must be quite the opposite of a conventional one.

Some physical value which is recognized invariable in time is taken for the basis of a standard. One of its values is taken for a unity. The number of these unities is (by means of measurement) in the other similar physical values. For example, size $0.3 \mathrm{~m}(M)$ means that the length of some object $(L)$ is 0.3 of a length unity (meter) or $L=0.3 \mathrm{~m}$.

The example shows that a standard and a unit are needed only to find out what share of a unit is in a measured value.

In the case of a purchasing power an estimation procedure is inverse. The economic theory and, what is more important, practice has originated a unique possibility. The possibility of estimating a digression of currency purchasing power from some unknown but fixed level. We are talking about inflation and deflation.

We know that if inflation in the current year is $50 \%$, it means that national currency purchasing power has fallen twice with regard to its unknown value of the last year.

Then if we take ruble purchasing power of the last year for a standard, purchasing power of a ruble last year will be 0.5 of a standard. Denoting purchasing power of a current ruble as $B_{\text {curr }}$ and taking purchasing power of a standard ruble $B_{s t}$ for a unity we will get $B_{c u r}=0.5 B_{s t}$.

This is the same result as in the example of measuring length $(L=0.3 \mathrm{~m})$.

However, it means:

Firstly, there is a principle possibility to estimate current purchasing power of any national currency in units of standard purchasing power.

Secondly, there appears a possibility to express (calculate) invariable value of standard purchasing power in values of current purchasing power of national currency.

For example, if today's inflation is estimated at $10 \%$, we can claim that $1+0.1=1.1$ currency units with current purchasing power corresponds to a unit of purchasing power.

It is important that an originated virtual standard of purchasing power is as invariable as a length standard.

\section{National currency setting up and use mechanism}

The only mission of regional currency and its setting up aim is provision of adequate comparison of various national currencies purchas- ing power. But the problem of comparison from the standpoint of standard use, as has been mentioned above, has two constituents.

The first, it is a sharp increase in precision and efficiency of estimation of national currencies digression from their current values. The estimation should become by an order more precise than it can be done at a stock exchange or by purchasing power parity estimation (PPP).

In practice the necessity of substantial precision increase of inflation and deflation estimation and efficiency of such estimations reception are considered.

The second, it is the necessity of estimation of actual correlation of different currencies purchasing power at the moment of supranational standard introduction and without this tool.

Actually, even knowing very accurate digression of each of the two currencies from their value at a certain moment nothing can be said about the correlation of their purchasing powers.

The first constituent of the problem of precision increase and currency purchasing power digression estimation efficiency has quite an obvious solution.

In modern conditions there are efficient methods of transition from fixing thousands of prices on goods-representatives (in the same way as working out inflation and PPP) to millions and also multiple efficiency increase of their changes.

Thus, the prices data for millions of different products can be operatively obtained and implemented while using contemporary ITtechnologies. No doubt, special modems used in cashier machines will allow transmitting online prices of millions of products to the analytical centre via Internet or satellite communication. The possibility to study such a load of information using contemporary computer methods is for sure. So today there is a technical possibility to increase multiple the representation and fluency of data analysis while calculating the deviation of purchasing power of national currency.

Practically the gist is in creation and foundation of multifunctional State System of Price Fxation (SSPF). The basis of which is automatic tracking of retail prices (products and services) deviation. But SSPF should also track wholesale prices and contracts prices.

The second constituent of this problem is the task of initial estimation of real correlation between purchasing powers of national currencies and standard which also can be resolved. It comes from the main requirement of practice to evaluate relative purchasing power of two currencies. The most important for the international business 
is that official figures of relative purchasing powers of two currencies (their rate) should maxi precisely correlate with real correspondence of their purchasing powers.

But this correlation can be only approximately corresponded with current rate, today officially taken as correlation of purchasing power of currencies in business operations. The real figures of relative purchasing power of currencies will be more precise which exclude random deviations if exchange rates and based on current trend. The closest will be the average figure of stock exchange rates of these currencies for a certain period (day, week, month) ${ }^{1}$ corrected to trend. This should be considered as the real correlation of purchasing power in a certain moment.

This correlation will allow further on calculating current real correlation of purchasing power of currencies at any time using deviation of their purchasing power from the fixed at the zero moment.

Then the algorithm of creating a supranational regional (world) currency and virtual standard of purchasing power can be the following.

Firstly, there should be created a Pool of countries, members of the treatment of supranational currency creation.

Secondly, the figure of purchasing power of a currency (member of a Pool) is taken as a measure at a certain period of time (zero moment) and this value is attributed to a unit of the supranational currency (SC) and considered standard.

Thirdly, there should be calculated initial correlation of purchasing power of each national currency and standard currency.

Fourthly, the State system of price fixation (SSPF) is implemented which tracks deviations of purchasing power of all countries - Pool members at zero moment and calculates absolute figures of their purchasing power in the terms of virtual standard. Including currencies which purchasing power at zero moment was taken as a value.

Fifthly, supranational regional currency (SRC) is founded and its value is legally attributed the purchasing power equal to virtual standard.

Supranational regional (world) currency starts working.

Before founding SRC it is important to understand the terms of its use. SRC use, at least at the initial stage, doesn't exclude stock exchange bidding but rationalizes its functions and creates a standard, practically anchor, which allows effectively limiting "chaos" of financial cataclysms.

\footnotetext{
${ }^{1}$ Methodology of estimation of initial real correlation of purchasing power of currencies should be created on the basis of special experiments.
}

Moreover, in the framework of the SRC mechanism there is a range of additional IT possibilities to enhance state regulation including those from price fixation system functions.

Although, while analyzing the perspectives of creation regional currencies, it is notable to remember the following: the method of currency rationalization should be considered as temporary as orientating at interests of world society in overall. The solution of regional pools problems and future currency-financial system is in the implementation of one standard of purchasing power of currency.

This very idea was in the sphere of interests of Nobel Prize laureate R. Mandell who unfortunately failed to make the last step to its solution. His works became the theoretical basis for single European currency (euro) creation [23, 24, 25]. Discussing the possibilities of using special rights of adoption SDR as the basis of world currency he wrote "To my mind SDR have the future as a single value (unit of account) occupying the central position in the core of international monetary system. To achieve this aim it should be transformed from the cart made of five inflation-open currencies into a unit which stays stable in the terms of its purchasing power" [6]. But the currency which "stays stable in the terms of its purchasing power" de facto is a standard of purchasing power.

\section{Candidates for the role of modern regional currency}

It should be noted that any regional and world currencies are used as a value of measure or standard for comparison while being estimated as purchasing power unit of different national currencies. Of course standard is unstable and unable to carry out precise calculations and consequently bad. Exactly from this point of view candidates for the role of modern regional currency should be considered.

Let's determine the essence of the term "purchasing power of national currency" [5]. Different sources provide similar definitions of this term. According to one of them "purchasing power is the ability to buy products (services) for a monetary unit. Purchasing power is correspondingly higher to the number of products (services) can be bought for a monetary unit” [21].

But as it seems the most accurate definition of this term is the following: "purchasing power is the economic index inversely proportional to the currency number which is necessary for consumer basket of goods and services". Decrease of purchasing power of currency is called inflation, increase of purchasing power - deflation" [14]. 
The difference of this definition is that we can track its average trait. But it is said about average character at the level of market basket that in the terms of purchasing power of national currency is not enough. The real definition of the term "purchasing power of national currency" and its practical essence are connected only with the use of average value of this ability for all the load of national currency.

Really exchange rate of any national currency expressed in the terms of foreign currency is always standard for all its units. Moreover if the values of purchasing power of certain units were different it would be illogical to talk about different prices for one product. For example the triple difference in prices for apples in the center and suburbs of Moscow wouldn't convey economic information if the ruble purchasing power was nonconstant.

This trait of monetary system was absolutely obvious and historically one of them metal monetary system. Monetary units for example which contained five grams of fold had the same purchasing power. But the purchasing power of these units with different weight loss and level of erasure didn't change at all.

This approach was acknowledged by the economic science long time ago and in the Walras's formulas "money is an interesting product..., its price is known beforehand. And equals to 1 ". [10, p. 417].

So the ability of money to have an average value of purchasing power of all monetary units is one of the necessary terms of any monetary system functioning. That is modern monetary system couldn't function and was useless without this trait.

So purchasing power of any unit of national currency in a certain moment of time is always the same. This is the fundamental characteristic of national currency.

Existing ideas to create international and regional currency appeal mostly to use unit which has stable golden basis or to create currency similar to special drawing rights (SDRs).

Concerning the problem of gold as standard of purchasing power we could refer to resume of modern monetary theories $[6,24,25]$ but the key argument in this serous and still discussable issue can be not only practice. In natural sciences no theories even the most convincing can be considered correct if experiments contradict their solutions. And even the most largescale as you can only imagine experiments to use golden standard failed completely at least twice.
Gold as the basis of state currency in different periods was used the dominant number of countries of the world. But to develop one effectively and survive in modern world all of them were forced to drop this idea. So, global experiment to use golden standard for a long time showed its ineffectiveness. For example the latest golden ruble in tsar Russia lasted for 15 years (1899-1914), in the Soviet Union - 1 year (1923) [13].

Just the same result was in another global experiment to use golden standard in international deals. We talk about widely-known Bretton-Woods international treatment dated 1944. The main issue was the requirement of constant golden support of dollar US [5,12]. The most powerful economy of the world failed to endure the burden of golden standard and after thirty years of complete fulfillment of the treaty the US were forced to breach it breaking all international commitments.

In other words cruel reality contrary to all speculations after some time always made drop golden standard. These arguments seem to be enough not to count on golden standard in context of modern world. But the reasons of its ineffectiveness are quite obvious [6, 20, 23].

The prevailing variant for today is to create international and regional currencies based on the principle of special drawing rights (SDR).

But the objective analysis shows that it doesn't solve the problems of regional and world currencies [1]. Let's prove this statement.

Today (2013) SDR is artificial absolutely noncash reserve currency emitted by the International monetary fund (IMF) to enlarge reserves and payments as to IMF credits [17]. "SDR rate is published every day and is determined by the dollar value of basket of four currencies: US dollar, euro, yen and pound... All currencies in the basket are revised every five years" [19].

Why are SDRs better than national currency as world currency? TO answer this question let's analyze SDR reaction to changes in rates of national currencies in the basket. For that we will take simplified analogue SDA which consists of US dollar (50\%) and euro (50\%) and we will consider that euro equals to two dollars. Under this correlation value of one SDR in US dollars is: $1 \times 1,5+$ $2 \times 0,5=0,5+1=1,5$ USD. Then dollar will cost $1: 1,5=0,67$ SDR, euro 2(USD) $: 1,5$ (USD) $=1,33$ SDR.

If purchasing power of dollar as a result of inflation will drop twofold and euro won't change ideally will cost 4 dollars. Then cost of a SDR will be: $1 \times 0,5+4 \times 0,5=0,5+2=2,5$ USD. Consequently value of dollar in SDR will become: 1 (USD) $: 2,5$ $=0,4$ SDR, euro will be: 4 (USD) : 2,5 (USD) $=1,6$ 
SDR. So in SDR measurement we have dollar inflation reflected as its price decreased and euro's increased. That is the gist of changing national currency to SDE as a world currency.

But as it can be seen from the figures dollar under the inflation twofold dropped less in measures of SDR than twofold (o,67: $0,4=1,67)$, euro in SDR increased clearly less than twofold (1,6:1,33 $=1,2$ ), so disproportionately to dollar inflation.

Relatively if there is euro inflation dollar will increase in SDR values but less than by euro inflation level and euro will drop but less than by its inflation level.

In overall the mechanism of SDR foundation leads to the idea that if dollar is under inflation and there is no other currency, SDR value in dollars will rise so that dollar will be overestimated and other currencies will be underestimated. If one of the currencies in the basket is subject to inflation (starts rating in dollar less than earlier) SDR value in dollars will decrease so that dollar estimation in SDR will rise less than by inflation rate of national currency. Alongside currency value which is subject to inflation measured in SDR will drop but less than by its inflation rate.

So, using SDR as world currency smoothes but doesn't eliminate the dependence of purchasing power value of any national currency on US dollar.

Moreover if global economic catastrophe takes place and all currencies in SDR basket including dollar will simultaneously lose their purchasing power even ten times, SDR will not change their value. So world currency based on SDR principle doesn't reflect real purchasing power of national currencies.

This conclusion can be illustrated by the following example. If at the bottom of world currency value there was gold cost, rate of any would drop ten times and more in the terms of world currency under the inflation of all currencies tenfold. But as it doesn't happen while using, that means that SDR even closely do not meet the requirements to the world currency.

In other words it can be stated that currency based on SDR principle will become bad regional currency. In its basis there will be a national currency and regional SDRs will not reflect real purchasing power of national currencies in cases of failure or economy boom or even world crisis and other global catastrophes.

\section{Conclusion}

It can be noted that the arguments given in the article allow stating that the only workable and dominant modern proposal concerning creation of regional currencies based on SDR doesn't solve the main problem of any regional currency. Its implementation doesn't eliminate the dependence of regional currency on any national one. The real way to solve the basic problem of currency unions and world monetary system is connected with the launch of total system of prices fixation and creation of virtual standard of purchasing power on its basis.

\section{References}

1. Asaliev A.M., Jusim V.N. (2012). Yadnatsionalnaya mirovaya valyuta I etalon pokupatelnoy sposobnosti. "Ekonomika ustoychivogo razvtiya" [Supranational World currency and purchasing power Standard. "Sound development economy"]. Regionalnyy nauchnayy zhurnal [Regional scientific magazine], 11, 26-40.

2. Bogomolov O. T. (2007). Mirovaya ekonomika v vek globalizatsii: uchebnik. Par. 5. Kollektivnyye valyuty [World Economy in the era of Globalization. Text-book. Collective Currencies] Moscow, Publishing House "Economics", 359.

3. Cheryomukhin A. Paritet pokupatelnoy sposobnosti i prichiny otkloneniya kursa rublya ot pariteta v Rossii. [Purchasing power parity and the reasons for the deviation of the ruble exchange rate parity in Russia]. Institut ekonomiki perekhonogo perioda. Moscva. Nauchnyye trudy 92R [Institute for the economy in transition. Moscow. Works no. 92R]. Available at: http://iep.ru/ files/text/working_papers/92. 117 page Pdf. (date of access: 20.05.13).

4. Entsiklopediya biznesa. Makroekonomika. Paradoks Triffina. [Encyclopedia of business. Macroeconomics. Paradox Triffina]. Available at: Http://profmeter [electronic resource]. com.ua/Encyclopedia/detail.php. (date of access: 12.04.13).

5. Faminsky I. (Ed.) (2001). Vneshneekonomichesky tolkovyy slovar [External Economic Dictionary], Moscow.

6. Globalistika entsikl. Mirovyye dengi [Globalistika: Encyclopedia. International money]. (2003). Moscow: Dialogue: Raduga, 1327.

7. Kratkaya istoriya mezhdunarodnykh sopostavleniy stoimostnykh pokazateley I obshchie printsipy ikh provedeniya [A brief history of international comparisons of values and common principles]. Available at" http://economics-online.ru/archives/326. (date of access: 16.05.13).

8. Kurs funta sterlingov k nemetskoy marke obvalilsya na $15 \%$, a k dollaru SShA na $25 \%$. Fond Dzhordzha Sorosa Kvantum poluchil igromnuyu pribyl [British pound sterling rate to a German mark collapsed by $15 \%$, and to US dollar - by $25 \%$. George Sorose's Foundation Quantum gained an enormous profit]. Available at: http://finbay.ru/vse-o-forex/samyj-izvestnyj-spekuljant. html. 12.07.12. (date of access: 06.06.13).

9. Lavrushina O. I. (2013). Dengi. Kredit. Banki [Money. Credit. Banks]. KNORUS, 448.

10. Maiburd E. M. (2000). Vvedenie v istoriyu ekonomicheskoy mysli. Ot prorokov do professorov [Introduction to History of Economic Thought From Prophets to Professors]. Moscow. Delo, 560.

11. Moiseev S. (2008). Rubl kak rezervnaya valyuta [Ruble as a reserve currency]. Voprosy ekonomiki [Economics Issues]. 9. 
12. Nazarbaev N. Klyuchi ot krizisa [Keys to Crisis], Russkaya gazeta [Russian Gazette], Federal issue, 4839, 02.02.2009.

13. Nureyev R. M. Bazovyye predposylki sovremennoy ekonomicheskoy (economics) teorii i kh kritika [Basic preconditions of modern economic theory (economics) and their criticism]. Doklad na zasedanii uchonogo soveta Instituta Ekonomiki RAN [The report of the meeting of the Scientific Council of the Institute of Economics of the RAS]. http://www.inecon.org/docs/Nureev_paper_2013.pdf., 28.10.2013. (date of access 20.11.13).

14. Pokupatelnaya sposobnost [Purchasing power]. Available at: http://ru.wikipedia.org/wiki/. (date of access: 7.11.12).

15. Polterovich V.M. (2011). Stanovlenie obshchego sotsialnogo analiza [Formation of General Social Analysis]. Obshchestvennyye nauki i sovremennost [Social Sciences and Contemporaneity], 2.

16. Soros J. (2008). Novaya paradigma finansovykh rynkov [The new paradigm for financial markets]. M. ed. Mann, Ivanov and Ferber, 192.

17. Spetsialnyye prava zaimstvovaniya. [Special drawing rights]. Available at: http://ru.wikipedia.org/wiki/SDR. (date of access: 20.09.12).

18. Spisok Vsemirnogo Banka (1990-2012) [List of World Bank (1990-2012)]. GDP (current US \$). World Bank. Available at: http://ru.wikipedia.org/wiki/. (date of access: 12.12.13).

19. Vyskazyvaniya V. Putina 1 avgusta 2011 goda vo vremya poseshcheniya foruma "Seliger-2011" v Tverskoy oblasti [Quoted from V. Putin's speech at the forum "Seleger-2011" in the Tver region]. Available at: http://www.tver-portal.ru/jandeks-novosti-menju, (fate of access: 12.04.13).

20. Yusim V. (2009). Pervoprichina mirovykh krizisov. [The Prime Cause of World Crises]. Voprosy ekonomiki [Economics Issues], 1.

21. Zaitsev N. I. (2000). Kratkiy slovar ekonomista [The short dictionary of economist].

22. Zolotoy rubl [Golden ruble]. Available at: http://ru.wikipedia.org/wiki/. (date of access: 20.05.13).

23. Mundell R. (1971). Theory: Interest, Inflation and Growth in the World Economy.

24. Randall WrayL. (2012). Modern Money Theory: A Primer on Macroeconomics for Sovereign Monetary Systems. Palgrave Macmillan, 312.

25. Rochon Louis-Philippe (Ed.), Sergio Rossi (Ed.) (2004). Modern Theories Of Money: The Nature And Role Of Money In Capitalist Economies. Edward Elgar Pub.

26. Triffin R. (1978). Gold and the Dollar Crisis: Yesterday and Tomorrow. Princeton University Press.

27. Samuelson P., Nordhaus V. (2008). Economics: translation from English: 16th ed. Moscow, Williams. 680.

\section{Information about the authors}

Asaliev Asali Magometalievich (Moscow, Russia) - Doctor of Economics, Professor, Dean of Marketing Department, Plekhanov Russian University of Economics (36 Stremyanny pereulok, Moscow, 117997, Russia, e-mail: a.am@bk.ru).

Yusim Vyacheslav Naumovich (Moscow, Russia) - Doctor of Economics, Professor of Economy and Organization of Industrial Production Department, Plekhanov Russian University of Economics (36 Stremyanny pereulok, Moscow, 117997, Russia, e-mail: vn62@yandex.ru).

Tarkhova Larisa Sergeevna (Moscow, Russia) - PhD, Professor, Head of Foreign Languages and Business Communication Department, Plekhanov Russian University of Economics (36 Stremyanny pereulok, Moscow, 117997, Russia, e-mail: laratarkhova@mail.ru). 